\title{
Ecosystem effects of fishing on the continental slope in the Central Mediterranean Sea
}

\author{
Mark Dimech $^{1,2,3, *}$, Michel J. Kaiser ${ }^{1}$, Sergio Ragonese ${ }^{4}$, Patrick J. Schembri ${ }^{3}$ \\ ${ }^{1}$ School of Ocean Sciences, Bangor University, Menai Bridge, Anglesey LL59 5AB, UK \\ ${ }^{2}$ Malta Centre for Fisheries Science (MCFS), Fort San Lucjan Marsaxlokk BBG06, Malta \\ ${ }^{3}$ Department of Biology, University of Malta, Msida MSD2080, Malta \\ ${ }^{4}$ Istituto per l'Ambiente Marino Costiero IAMC/CNR Section of Mazara, Via Vaccara 61, 91026 Mazara del Vallo (TP), Italy
}

\begin{abstract}
Fishing with demersal towed gears can have dramatic effects on the structure and functioning of marine ecosystems. We studied the ecosystem effects of the deep-sea red shrimp Aristaeomorpha foliacea trawl fishery $(500$ to $800 \mathrm{~m}$ ) in the Strait of Sicily, at the population and community level by sampling in trawled and non-trawled sites as determined by vessel monitoring system (VMS) fishing effort data. The study was conducted within the Maltese 25 nautical mile Fisheries Management Zone as part of the ongoing MEDITS trawl survey. Samples were collected using an experimental otter trawl net with a cod-end stretched mesh size of $20 \mathrm{~mm}$, from 7 stations located in trawled sites (mean depth $616 \pm 26 \mathrm{~m}$ ) and from 7 stations in non-trawled sites (mean depth $556 \pm 40 \mathrm{~m}$ ). Population and community indicators were compared across the trawled and non-trawled sites. Populations of $A$. foliacea and Etmopterus spinax did not show any differences in biomass between the trawled and non-trawled sites, whereas the biomass of Plesionika martia, Nephrops norvegicus, Helicolenus dactylopterus dactylopterus and Galeus melastomus was 4 times, 16 times, 6 times and 2 times higher, respectively, at the non-trawled sites. Changes in length structure were also detected for all species except for E. spinax. At the community level, higher biomass, density and diversity indices were recorded at the non-trawled sites. Despite the clear evidence of ecosystem changes due to fishing, the main target species, A. foliacea and $P$. martia, had a high resilience to trawling activities. Setting up trawling lanes as a management option would likely minimise negative impacts on species with slow growth rates and low resilience.
\end{abstract}

KEY WORDS: Strait of Sicily · Fishing impacts - Trawl surveys - Mediterranean - Demersal resources $\cdot$ Red shrimp

Resale or republication not permitted without written consent of the publisher

\section{INTRODUCTION}

Bottom trawling can have dramatic effects on the structure and functioning of marine ecosystems (Hall 1999, Kaiser \& de Groot 2000, Smith et al. 2000). These effects include physical damage to the seabed and degradation of associated communities, overfishing of demersal resources, high amounts of bycatch and discards, and a greater reduction in the mean body size within the fish assemblage than for other more selective fisheries (Beverton \& Holt 1957, Hall 1999, Jennings et al. 1999, Kaiser \& de Groot
2000). Ecosystem modifications are triggered by the change in the biomass and demographic structure of the different species as well as by the increasing food supply for scavenging and opportunistic species (Kaiser \& Spencer 1994, Ramsay et al. 1998, Demestre et al. 2000). In addition, the removal of benthic biomass has been linked to a break in benthopelagic coupling, which may result in a shift of the biotic communities in some temperate systems (Choi et al. 2004).

Although over 100 studies have explored the effects of fishing on benthic assemblages, there remain 
considerable gaps for some systems (Lindeboom \& de Groot 1998, Kaiser \& de Groot 2000, Kaiser et al. 2006). In particular, this applies to the Mediterranean Sea since this sea is markedly different from the global ocean due to its oligotrophic status, high salinity, high water temperatures $\left(12\right.$ to $15^{\circ} \mathrm{C}$ below the thermocline at ca. 50 to $100 \mathrm{~m}$ ), mostly microtidal nature and a relatively more extreme range of depths. The oligotrophic nature of the Mediterranean results in a generally lower abundance of species and a smaller mean individual biomass than in adjacent Atlantic waters. These factors have often led to the sweeping conclusion that in the Mediterranean, areas with a low biomass are overfished.

The continental slope in the central Mediterranean is dominated by soft-bottom communities (Pérès 1985) that are characterised by decapod assemblages (Cartes 1993, Cartes et al. 2004) comprising species of tropical or subtropical origin (e.g. Aristaeomorpha foliacea, Parapenaeus longirostris). The dominant fish species are sharks such as Galeus melastomus and Etmopterus spinax (Stefanescu et al. 1992). The crustacean decapods are more important in terms of production in such oligotrophic conditions when compared to shallower waters, probably due to their low levels of food consumption (Cartes \& Sardà 1992). These decapods are not only detritivores or scavengers, but also highly size-selective predators (Cartes 1993).

Bottom trawling at depths ranging from 50 to $800 \mathrm{~m}$ is an important component of many Mediterranean fisheries (Papaconstantinou \& Farrugio 2000, Lleonart 2005). Trawl catches are composed of a highly diverse mix of fish (teleosts and elasmobranchs), cephalopods and crustaceans (decapods and stomatopods), together with several macroepibenthic invertebrates (Caddy 1993, Relini et al. 1999). One of the most important trawl fisheries in the Mediterranean is that for deep-sea red shrimps (Aristaeomorpha foliacea and Aristeus antennatus) that occur on the continental slope at depths from 500 to 800 m (Caddy 1993, Moranta et al. 2000). These shrimps are fished with gear that has a cod-end mesh size of 24 to $26 \mathrm{~mm}$.

In the deep Mediterranean, few studies have examined the effects of bottom trawling on demersal resources. This is mainly due to the large depth range targeted by demersal fisheries and the zonation of demersal assemblages with depth, both factors making it more difficult to address the effects of trawling. The few studies undertaken to date deal with the impact of trawling on the demersal ecosystems of the continental shelf (Caddy 2000, Pipitone et al. 2000, Sánchez et al. 2000, de Juan et al. 2007,
Dimech et al. 2008), the shelf break (Smith et al. 2000, Gristina et al. 2006) and of the deep slope (Papaconstantinou \& Kapiris 2003, D'Onghia et al. 2005). Although there are also a number of studies on discards from trawling activities (Sartor et al. 1999, Sánchez et al. 2007), to date there are no studies for the deep-slope demersal resources of the Mediterranean which compare populations and communities in trawled and non-trawled sites based on detailed data on fishing effort. Some existing studies have compared sites with relatively high and low fishing intensities, but none has provided quantitative data on the fishing effort in the sites compared. Furthermore, the deep-water trawl fishery for red shrimps can be considered as 'monospecific' (with either of the 2 red shrimp species being dominant in the catch) relative to the trawl fisheries on the continental shelf and upper slope. In addition, red shrimps are exclusively harvested by bottom otter trawls, whereas a variety of gears are used on the continental shelf and upper slope (Papaconstantinou \& Farrugio 2000, Lleonart 2005). This situation provides an opportunity to assess the ecological impacts of bottom trawling on demersal resources and to provide advice on how to manage the trawl fisheries in line with the ecosystem approach to fisheries management.

The aim of the present study was to quantify the ecosystem effects of the Mediterranean deep-sea (500 to $800 \mathrm{~m}$ ) red shrimp trawl fishery by examining responses in population and community structure and size spectra of the continental slope. The study also utilised a sampling design based on known trawled and non-trawled sites as determined from vessel monitoring system (VMS) data.

\section{MATERIALS AND METHODS}

\section{Sampling}

The present study was conducted within the 25 nautical mile (n mile) Fisheries Management Zone (FMZ) around the Maltese islands. The study was part of the ongoing MEDITS trawl survey programme (Bertrand et al. 2002). Otter trawl samples were collected by the RV 'Sant'Anna' during July 2007 from 7 stations located in trawled sites and 7 stations from non-trawled sites (Fig. 1); 1 haul was made per station. The depth ranged between 517 and $671 \mathrm{~m}$, with a mean $( \pm \mathrm{SD})$ depth of $616 \pm 26 \mathrm{~m}$ for the trawled sites and $556 \pm 40 \mathrm{~m}$ for the non-trawled sites. The difference between the mean depths was kept to a minimum to avoid the confounding effect of 
bathymetric changes in population and community structure. Areas trawled by the commercial fishery were identified using VMS data for the years 2006 and 2007. Sampling stations from non-trawled sites were chosen randomly outside the trawled areas. Fishing effort for the trawlers operating in the areas was calculated from the VMS data after filtering by considering vessel speeds of between 2 and 4 knots to be indicative of trawling on the deep slope, because in the Mediterranean, trawlers travel at an average speed of 2 to 3 knots when trawling at such depths. Trawling grounds were identified using VMS data and mapping using GIS techniques. Trawling effort for the years 2006 and 2007 was calculated as number of days fishing, gross tonnage multiplied by days $(\mathrm{GT} \times \mathrm{d})$ and kilowatts multiplied by days $(\mathrm{kW} \times \mathrm{d})$; the total swept area was ca. $100 \mathrm{~km}^{2}$ (Table 1). The trawling effort in the non-trawled areas was 0.

Each sampling haul lasted for 45 to $60 \mathrm{~min}$, and trawl speed was ca. 3 knots. Samples were collected using a 20 to $22 \mathrm{~m}$ wide and $40 \mathrm{~m}$ long otter trawl net with a 2 to $2.5 \mathrm{~m}$ vertical opening and a cod-end stretched mesh size of $20 \mathrm{~mm}$ (IFREMER GOC 73; Fiorentini et al. 1999). Further survey specifications can be found in Relini et al. (2008). The entire biological component from each haul was sorted, after which the fauna were identified, weighed and counted. Additional parameters were also collected

Table 1. Trawling effort estimates for the trawled areas in kilowatt days $(\mathrm{kW} \times \mathrm{d})$ and gross tonnage days $(\mathrm{GT} \times \mathrm{d})$

\begin{tabular}{|ccccc|}
\hline Year & $\begin{array}{c}\text { No. of } \\
\text { trawlers }\end{array}$ & $\begin{array}{c}\text { Total fishing } \\
\text { days }\end{array}$ & \multicolumn{2}{c|}{$\begin{array}{c}\text { Total effort } \\
(\mathrm{kW} \times \mathrm{d})\end{array}$} \\
$(\mathrm{GT} \times \mathrm{d})$ \\
\hline 2006 & 8 & 523 & 205702 & 43503 \\
2007 & 7 & 329 & 110187 & 23992 \\
\hline
\end{tabular}

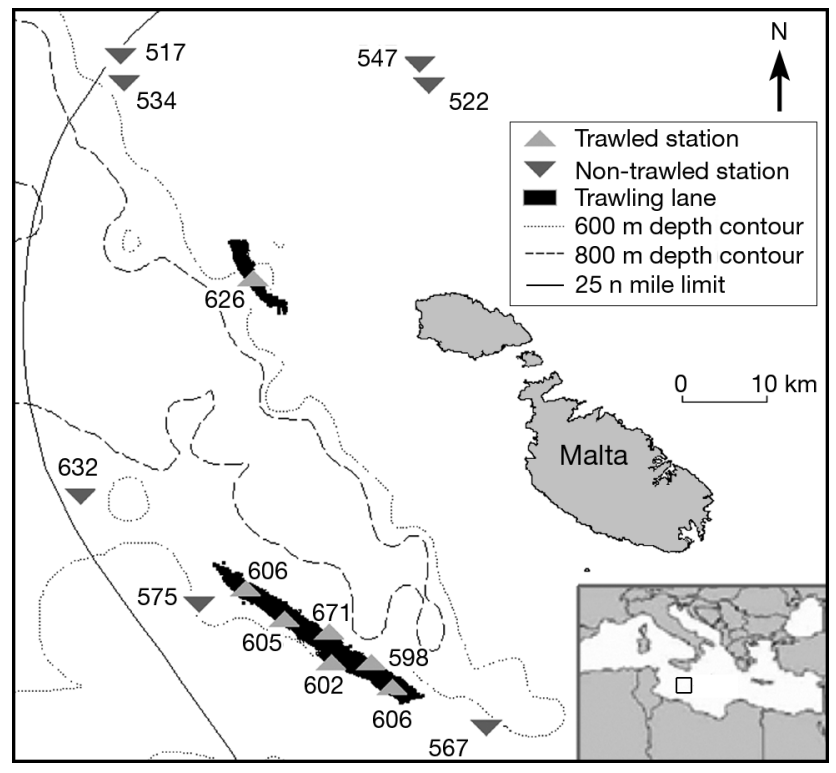

Fig. 1. Sampling stations with their respective mean depths $(\mathrm{m})$ in the $25 \mathrm{n}$ mile zone around Malta. The vessel monitoring system (VMS) positions were recorded every $2 \mathrm{~h}$, and the plotted positions indicate the trawling lanes

for the MEDITS target species, including length, weight and sex (Bertrand et al. 2002, Relini et al. 2008), and in addition, population parameters were collected for the pandalid shrimp Plesionika martia and all elasmobranchs.

\section{Population level analysis}

We examined differences in population parameters for individual species (Table 2) as well as differences in assemblage characteristics between trawled and non-trawled sites. The species selected for compari-

Table 2. Species selected for the analysis at the population level, with an indication of their ecological characteristics, commercial importance and maximum recorded length in the Mediterranean (where indicated, cited studies measured only one gender). CL: carapace length; TL: total length

\begin{tabular}{|c|c|c|c|c|}
\hline Species & Common name & $\begin{array}{l}\text { Ecological } \\
\text { characteristic }\end{array}$ & $\begin{array}{l}\text { Commercial } \\
\text { importance }\end{array}$ & Max. recorded length \\
\hline Aristaeomorpha foliacea & Giant red shrimp & Opportunistic & High & CL 70 mm (o; Ragonese et al. 1994) \\
\hline Plesionika martia & Golden shrimp & Opportunistic & Medium & CL 26 mm (Maiorano et al. 2000) \\
\hline Nephrops norvegicus & Norway lobster & Sedentary & High & CL 79 mm (Mytilineou et al. 1998) \\
\hline $\begin{array}{l}\text { Helicolenus dactylopterus } \\
\text { dactylopterus }\end{array}$ & Bluemouth rockfish & Sedentary & Medium & TL $36.1 \mathrm{~cm}\left(0^{7} ;\right.$ Ribas et al. 2006) \\
\hline Galeus melastomus & Blackmouth catshark & $\begin{array}{l}\text { Active predator } \\
\text { and scavenger }\end{array}$ & Low & TL 52 cm (o; Serena 2005) \\
\hline Etmopterus spinax & Velvet belly shark & $\begin{array}{l}\text { Active predator } \\
\text { and scavenger }\end{array}$ & None & TL 60 cm (Serena 2005) \\
\hline
\end{tabular}


Table 3. Population and community level variables analysed for the trawled and non-trawled sites sampled. All variables are expected to decrease as a result of fishing, except $\mathrm{L}_{\text {opt }}$ and $\mathrm{L}_{\infty}$ (not applicable). Length units: $\mathrm{mm}$ (crustaceans), $\mathrm{cm}$ (fish)

\begin{tabular}{|c|c|}
\hline Indicator & Definition \\
\hline \multicolumn{2}{|l|}{ Population } \\
\hline$\overline{\mathrm{BI}}$ & Mean biomass index $\left(\mathrm{kg} \mathrm{km}^{-2}\right)$ \\
\hline$\overline{\mathrm{DI}}$ & Mean density index (no. ind. $\mathrm{km}^{-2}$ ) \\
\hline$\overline{\mathrm{W}}$ & Mean individual weight $(\mathrm{g})$ \\
\hline$\overline{\mathrm{TL}}$ or $\overline{\mathrm{CL}}$ & Mean individual length \\
\hline$\overline{\mathrm{L}}_{\max }$ & Mean maximum length per treatment \\
\hline $\mathrm{L}_{\max }$ & Recorded maximum length \\
\hline $\mathrm{L}_{\mathrm{opt}}$ & Theoretical optimal size \\
\hline $\mathrm{L}_{\mathrm{m}}$ & Length at maturity \\
\hline $\mathrm{L}_{\infty}$ & Asymptotic length \\
\hline \multicolumn{2}{|l|}{ Community } \\
\hline $\mathrm{BI}_{\mathrm{t}}$ & Mean total biomass index $\left(\mathrm{kg} \mathrm{km}^{-2}\right)$ \\
\hline$\underline{B I}_{\text {teleosts }}$ & Mean teleost biomass index $\left(\mathrm{kg} \mathrm{km}^{-2}\right)$ \\
\hline $\mathrm{BI}_{\text {Chondrichthyes }}$ & $\begin{array}{l}\text { Mean Chondrichthyes biomass index } \\
\left(\mathrm{kg} \mathrm{km}^{-2}\right)\end{array}$ \\
\hline$\overline{\mathrm{BI}}_{\text {decapods }}$ & Mean decapod biomass index $\left(\mathrm{kg} \mathrm{km}^{-2}\right)$ \\
\hline & Mean total density index (no. ind. $\mathrm{km}^{-2}$ ) \\
\hline$\overline{\mathrm{DI}}_{\text {teleosts }}$ & Mean teleost density index (no. ind. $\mathrm{km}^{-2}$ ) \\
\hline$\overline{\mathrm{DI}}_{\text {Chondrichthyes }}$ & $\begin{array}{l}\text { Mean Chondrichthyes density index } \\
\text { (no. ind. } \mathrm{km}^{-2} \text { ) }\end{array}$ \\
\hline$\overline{\mathrm{DI}}_{\text {decapods }}$ & $\begin{array}{l}\text { Mean decapod density index (no. ind. } \\
\mathrm{km}^{-2} \text { ) }\end{array}$ \\
\hline$\overline{\mathrm{S}}$ & Mean total number of species \\
\hline $1-\lambda$ & Mean Simpson diversity index \\
\hline $\mathrm{D}$ & Mean Margalef species richness \\
\hline $\mathrm{H}^{\prime}$ & $\begin{array}{l}\text { Mean Shannon-Wiener diversity index } \\
\left(\log _{e}\right)\end{array}$ \\
\hline$\underline{\mathrm{J}}^{\prime}$ & Mean Pielou's evenness \\
\hline$\Delta$ & Mean taxonomic diversity index \\
\hline$\Delta^{*}$ & Mean taxonomic distinctness index \\
\hline$\Lambda^{+}$ & Mean variation in taxonomic distinctness \\
\hline
\end{tabular}

son of their response to trawled and non-trawled sites varied in their life-history characteristics and habitat preferences (Table 2).

The variables measured at the population level are listed in Table 3. The number of individuals per species and size class for each haul was standardised per $\mathrm{km}^{2}$, and the length frequency distributions (LFDs) for each species at the trawled and non-trawled sites were plotted. Population status was assessed from length frequency data using the methods described by Froese \& Binohlan (2000). The parameters estimated included the theoretical optimal size $\left(\mathrm{L}_{\mathrm{opt}}\right)$, which is the length at which a cohort maximises its production (maximum possible yield per recruit), the length at maturity $\left(\mathrm{L}_{\mathrm{m}}\right)$ and the asymptotic length $\left(\mathrm{L}_{\infty}\right)$, which is the mean length the animals of a given population would reach if they were to grow forever according to the Von Bertalanffy Growth Function (VBGF). $\mathrm{L}_{\text {opt }}$ was estimated using the VBGF parameters for Aristaeomorpha foliacea (derived from
Ragonese et al. 1994), Plesionika martia (derived from Maiorano et al. 2000), Nephrops norvegicus (derived from Ragonese et al. 2004) and Helicolenus dactylopterus dactylopterus (derived from Ragonese et al. 2004), while for Galeus melastomus and Etmopterus spinax it was estimated from $\mathrm{L}_{\infty}$ (Froese \& Binohlan 2000), since no growth parameters were found for these 2 species. $L_{o p t}$ and $L_{m}$ were superimposed onto the LFD plots, and the percentage number of individuals less than $\mathrm{L}_{\mathrm{m}}$ and $\mathrm{L}_{\mathrm{opt}}$ was calculated for the trawled and non-trawled sites. When most of the individuals were below $\mathrm{L}_{\mathrm{m}}$ and $\mathrm{L}_{\mathrm{opt}}$, the population was classified as overfished; when most of the individuals were between $\mathrm{L}_{\mathrm{m}}$ and $\mathrm{L}_{\mathrm{opt}}$, the population was classified as lightly fished, and when most of the individuals were above the $\mathrm{L}_{\mathrm{m}}$ and $\mathrm{L}_{\mathrm{opt}}$, the population was classified as unexploited (Froese \& Binohlan 2000).

\section{Community level analysis}

The total abundance indices (DI and BI) for each station, standardised per $\mathrm{km}^{2}$, were computed for fish, crustaceans and cephalopods. Only the biomass data were used for further community analysis, since these gave more clearly interpretable results (Dimech et al. 2008). The BI for each station was analysed using multivariate classification and ordination techniques. A similarity matrix was constructed from the fourth-root transformed data using the Bray-Curtis similarity measure, following which agglomerative hierarchical clustering and non-metric multidimensional scaling (nMDS) ordination were applied (Clarke \& Warwick 2001a). The SIMPROF analysis was performed to check the significance of the clusters. The SIMPER procedure was used to determine which species contributed most to the dissimilarity between the trawled and non-trawled stations (Clarke \& Warwick 1994). The analysis of similarities (ANOSIM) routine was used to test for differences between the 2 sites. All statistical analyses were performed using the PRIMER 6.1.13 software package (Clarke \& Warwick 2001a).

Biodiversity indicators and other univariate parameters (Table 3) were calculated for each station to test the utility of each indicator in detecting differences between the trawled and non-trawled sites. Taxonomic diversity indices were also calculated (Table 3), since these take into account the functional differences between species (Clarke \& Warwick 1998, 2001b). The taxonomic diversity indices were computed based on the suggestions and methods for 
the Mediterranean described by Merigot et al. (2007), although we included all species in the calculations rather than only the ground fish (as was done by Merigot et al. 2007). This enabled us to compare the results of the taxonomic diversity indices with the other biodiversity indices, and to account for the strong component of decapod species that characterise the deep slope (Dimech et al. 2008).

Size spectra were calculated for the trawled and non-trawled sites using the weights of individuals from all taxonomic groups, including teleosts, elasmobranchs, crustaceans and cephalopods. Since different hauls did not sweep equal areas of the seabed, weights were standardised $\left(\mathrm{g} \mathrm{km}^{-2}\right)$, after which each individual was assigned to a weight class $\left(\log _{2}\right.$ weight in g). The data were normalised, and the logarithm of the biomass was calculated. Lower and upper size classes were excluded to avoid data artefacts due to poor retention of specific size classes in the gear (Duplisea et al. 1997, Jennings et al. 2001).

Differences between the univariate parameters calculated at the population and community level were analysed using the non-parametric 2-sample Mann-Whitney $U$-test, because the data did not meet the assumptions of a parametric test.

\section{RESULTS}

\section{Population level}

In total, 1191 and 2608 individuals were caught from the trawled and non-trawled sites, respectively. The red shrimp Aristaeomorpha foliacea was dominant in terms of abundance (DI), and the blackmouth catshark Galeus melastomus dominated in terms of total weight (BI). A comparison of the size-class frequency distributions for individual species sampled at the trawled and non-trawled sites revealed similarities in the frequency distribution of individuals among size classes; however, the number of individuals in each size class was clearly much lower at the trawled sites compared with the non-trawled sites (Fig. 2).

Aristaeomorpha foliacea. Neither BI nor DI were significantly different (Mann-Whitney $U$-test, p > 0.05; Table 4) between the trawled and non-trawled sites. However, from the LFD analysis, it is clear that a larger number of recruits (mostly females; carapace length [CL] 27 to $33 \mathrm{~mm}$ ) were present at the nontrawled sites, whereas larger individuals (females; CL 54 to $63 \mathrm{~mm}$ ) were more prevalent at the trawled sites (Fig. 2). The mean CL and mean individual weight were significantly higher at the trawled sites (Mann-Whitney $U$-test $\mathrm{p}<0.05$; Fig. 2), while the mean maximum CL was not significantly different. The LFD analysis showed that $51 \%$ and $75 \%$ of the individuals were less than $\mathrm{L}_{\mathrm{m}}$, and $85 \%$ and $97 \%$ were less than $\mathrm{L}_{\text {opt }}$ in the trawled and non-trawled sites, respectively. These values were relatively high when one considers that a portion of the population are males (mostly between CL 36 and $46 \mathrm{~mm}$ ), which mature at about CL 30 to $33 \mathrm{~mm}$ (Ragonese et al. 2004). However, the percentage of individuals below the $\mathrm{L}_{\text {opt }}$ from the trawled sites was much lower than that from the non-trawled sites, which indicates a higher fishing intensity in the trawled sites with the less mobile new recruits and juveniles being heavily impacted in the trawl lane.

Plesionika martia. For P. martia, BI and DI were significantly higher (Mann-Whitney $U$-test $\mathrm{p}<0.05$; Table 4) and almost 4 times higher at the non-trawled compared with the trawled sites. However, mean CL was not significantly different (Mann-Whitney $U$ test $\mathrm{p}>0.05$ ), although a higher mean individual weight was recorded at the trawled sites. The LFD was very similar at the 2 sites except for the higher number of juveniles and adults at the non-trawled sites. The LFD analysis indicated an apparently healthy, lightly fished population with most individuals above the size at first maturity and within the range of $\mathrm{L}_{\text {opt }}$.

Nephrops norvegicus. For $N$. norvegicus, BI and DI were much higher (16 times higher, Mann-Whitney $U$-test $\mathrm{p}<0.05$; Table 4 ) at the non-trawled sites compared to the trawled sites. However, mean CL and mean individual weight were not significantly different (Mann-Whitney $U$-test p > 0.05; Table 4). The LFD was very different between the 2 sites investigated, with a larger proportion of $N$. norvegicus in the higher size classes at the non-trawled sites, and with a significantly higher mean maximum CL (Mann-Whitney $U$-test $\mathrm{p}<0.05$; Table 4). The LFD analysis indicated that $27 \%$ and $12 \%$ of the individuals were less than $\mathrm{L}_{\mathrm{m}}$, and $62 \%$ and $59 \%$ were less than $\mathrm{L}_{\mathrm{opt}}$ at the trawled and non-trawled sites, respectively. Although a greater number of individuals less than $\mathrm{L}_{\mathrm{m}}$ were recorded at the trawled sites, and the populations at both sites had more than $40 \%$ of the individuals larger than $\mathrm{L}_{\text {opt }}$, the $N$. norvegicus population at the trawled sites seems to be overexploited, as biomass was 16 times higher at the non-trawled sites (where the population is clearly unexploited).

Helicolenus dactylopterus dactylopterus. BI and DI were significantly higher (6 times higher, Mann- 

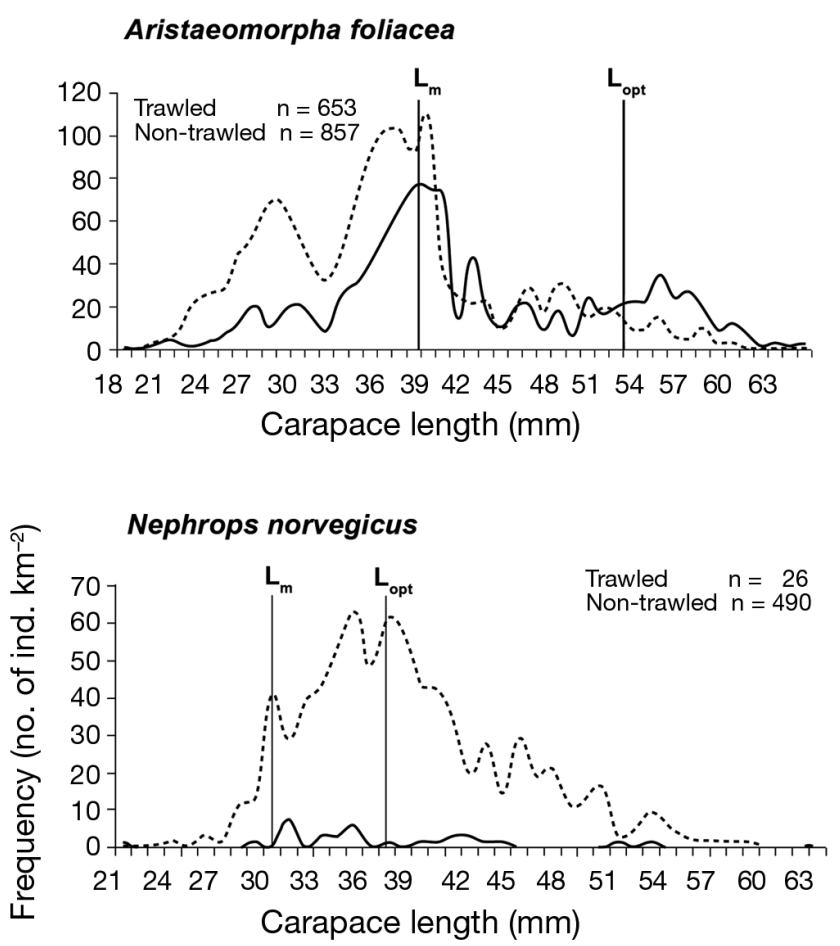

Galeus melastomus

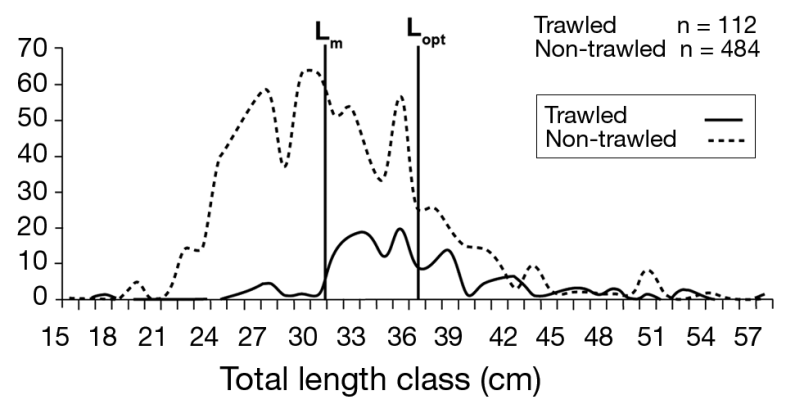

Plesionika martia

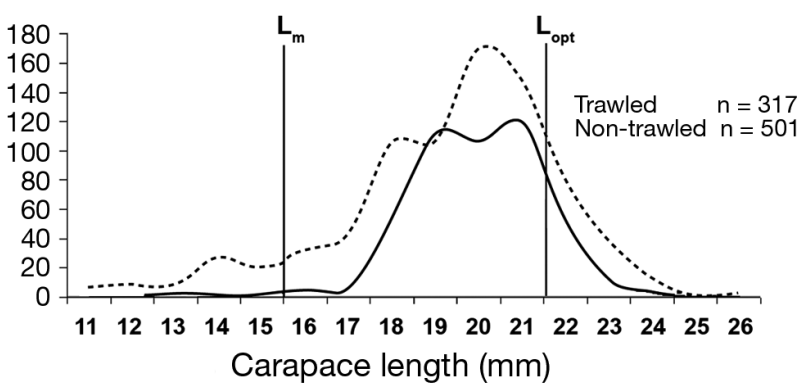

Helicolenus dactylopterus dactylopterus

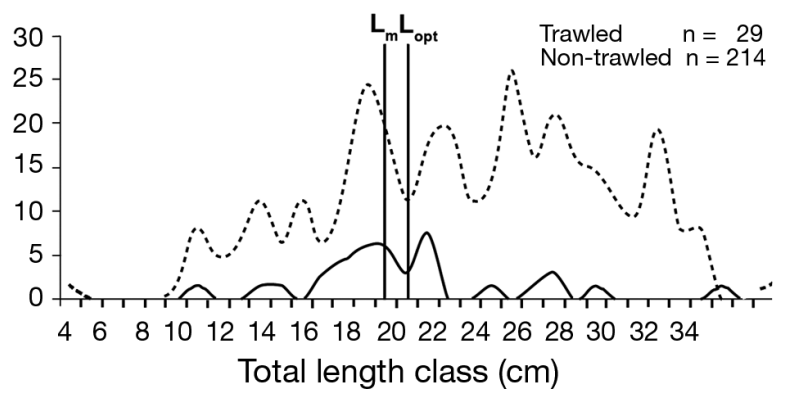

Etmopterus spinax

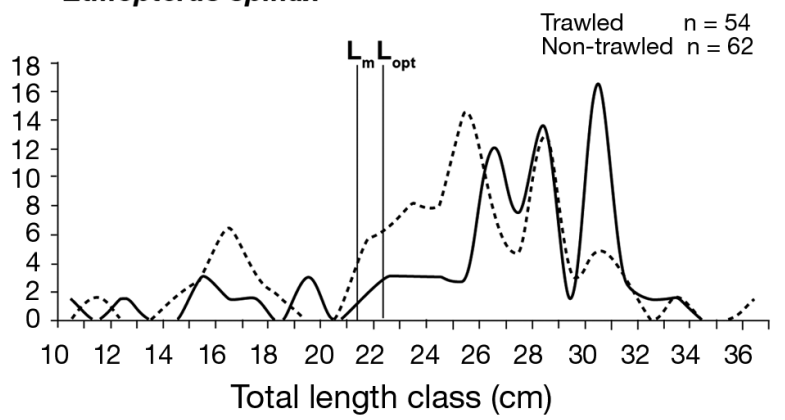

Fig. 2. Length frequency distributions for Aristaeomorpha foliacea, Plesionika martia, Nephrops norvegicus, Helicolenus dactylopterus dactylopterus, Galeus melastomus and Etmopterus spinax at trawled and non-trawled sites. $\mathrm{L}_{\mathrm{m}}$ : length at first maturity; $\mathrm{L}_{\text {opt }}$ : theoretical optimal size

Whitney $U$-test $\mathrm{p}<0.05$; Table 4) at the nontrawled sites than at the trawled ones. Mean total length (TL) and mean individual weight were not significantly different (Mann-Whitney $U$-test $\mathrm{p}>$ 0.05; Table 4) for these species in the 2 areas. The LFD showed a high number of individuals in the larger size classes (TL 26 to $36 \mathrm{~cm}$ ), but the mean maximum TL was not significantly different (MannWhitney $U$-test $\mathrm{p}>0.05$; Table 4 ). The LFD analysis showed that $55 \%$ and $34 \%$ of the individuals were less than $\mathrm{L}_{\mathrm{m}}$, and $79 \%$ and $42 \%$ were less than $\mathrm{L}_{\mathrm{opt}}$ at the trawled and non-trawled sites, respectively. These results suggest that there is overfishing at the trawled sites but that there are healthy and unfished populations at the non-trawled sites.
Galeus melastomus. Although BI was twice as high at the non-trawled sites, this difference was not significant; however, DI was significantly higher (3 times higher, Mann-Whitney $U$-test $\mathrm{p}<0.05$; Table 4) at the non-trawled sites. Mean TL and mean individual weight were significantly higher (Mann-Whitney $U$-test $\mathrm{p}<0.05$; Table 4 ) at the trawled sites. The LFD showed a larger proportion of juvenile individuals (TL 24 to $30 \mathrm{~cm}$ ) at the non-trawled sites. The LFD analysis showed that $27 \%$ and $64 \%$ of the individuals were less than $\mathrm{L}_{\mathrm{m}}$, and $68 \%$ and $87 \%$ were less than $\mathrm{L}_{\mathrm{opt}}$ at the trawled and non-trawled sites, respectively. These results clearly demonstrate a recruitment overfishing at the trawled sites and unfished populations at the non-trawled sites. 
Table 4. Mean \pm SD values for biomass and density indices, body length, weight and maximum length, together with the results of Mann-Whitney $U$ analysis between the trawled and non-trawled sites. Indices are defined in Table $3 .{ }^{*} \mathrm{p}<0.05$

\begin{tabular}{|c|c|c|c|c|c|c|}
\hline & $\begin{array}{c}\overline{\mathrm{BI}} \\
\left(\mathrm{kg} \mathrm{km}^{-2}\right)\end{array}$ & $\begin{array}{c}\overline{\mathrm{DI}} \\
\text { (no. ind. } \mathrm{km}^{-2} \text { ) }\end{array}$ & $\begin{array}{l}\bar{W} \\
(g)\end{array}$ & $\begin{array}{l}\overline{\mathrm{CL}} \\
(\mathrm{mm})\end{array}$ & $\begin{array}{l}\overline{\mathrm{L}}_{\max } \\
(\mathrm{mm})\end{array}$ & $\begin{array}{r}\mathrm{L}_{\max } \\
(\mathrm{mm})\end{array}$ \\
\hline \multicolumn{7}{|c|}{ Aristaeomorpha foliacea } \\
\hline Trawled & $26.3 \pm 5.5$ & $979 \pm 296$ & $28.21 \pm 6.62$ & $42.19 \pm 3.5$ & $61.00 \pm 3.7$ & 65 \\
\hline Non-trawled & $28.5 \pm 21.9$ & $1534 \pm 1037$ & $17.86 \pm 3.34$ & $35.95 \pm 2.67$ & $56.57 \pm 3.95$ & 60 \\
\hline$U$ & 24 & 17 & 3 & 2 & 10 & \\
\hline $\mathrm{p}$ & 0.949 & 0.338 & $0.006^{*}$ & $0.004^{*}$ & 0.053 & \\
\hline \multicolumn{7}{|c|}{ Plesionika martia } \\
\hline Trawled & $3.4 \pm 2.0$ & $606 \pm 374$ & $5.73 \pm 0.36$ & $19.91 \pm 0.33$ & $23.17 \pm 0.75$ & 24 \\
\hline Non-trawled & $11.3 \pm 7.1$ & $2253 \pm 1307$ & $4.87 \pm 0.75$ & $19.24 \pm 1.23$ & $23.83 \pm 1.72$ & 26 \\
\hline$U$ & 8 & 6 & 5 & 9 & 16 & \\
\hline $\mathrm{p}$ & $0.035^{*}$ & $0.018^{*}$ & $0.037^{*}$ & 0.15 & 0.73 & \\
\hline \multicolumn{7}{|c|}{ Nephrops norvegicus } \\
\hline Trawled & $1.9 \pm 2.8$ & $46 \pm 63$ & $40.76 \pm 23.2$ & $36.50 \pm 7.01$ & $41.00 \pm 10.49$ & 53 \\
\hline Non-trawled & $33.7 \pm 35.5$ & $749 \pm 811$ & $45.64 \pm 9.91$ & $38.46 \pm 2.42$ & $55.00 \pm 5.57$ & 63 \\
\hline$U$ & 0 & 0 & 12 & 11 & 19 & \\
\hline $\mathrm{p}$ & $0.004^{*}$ & $0.004^{*}$ & 0.372 & 0.291 & $0.030^{*}$ & \\
\hline \multicolumn{7}{|c|}{ Helicolenus dactylopterus dactylopterus } \\
\hline Trawled & $8.2 \pm 13.5$ & $51 \pm 63$ & $119.4 \pm 55.1$ & $18.9 \pm 2.6$ & $22.4 \pm 7.1$ & 35,2 \\
\hline Non-trawled & $72.8 \pm 81.2$ & $378 \pm 319$ & $139.6 \pm 82.5$ & $18.7 \pm 4.7$ & $28.0 \pm 7.7$ & 37 \\
\hline$U$ & 7 & 3 & 18 & 19 & 34 & \\
\hline $\mathrm{p}$ & $0.046^{*}$ & $0.010^{*}$ & 0.668 & 0.775 & 0.25 & \\
\hline \multicolumn{7}{|c|}{ Galeus melastomus } \\
\hline Trawled & $40.9 \pm 45.1$ & $169 \pm 156$ & $252.1 \pm 128$ & $37.5 \pm 4.6$ & $48.0 \pm 6.8$ & 57 \\
\hline Non-trawled & $84.8 \pm 57.4$ & $716 \pm 423$ & $120.5 \pm 38.9$ & $31.7 \pm 3.6$ & $46.4 \pm 5.9$ & 54 \\
\hline$U$ & 12 & 5 & 7 & 7 & 50 & \\
\hline $\mathrm{p}$ & 0.11 & $0.013^{*}$ & $0.025^{*}$ & $0.025^{*}$ & 0.701 & \\
\hline \multicolumn{7}{|c|}{ Etmopterus spinax } \\
\hline Trawled & $7.5 \pm 4.82$ & $81 \pm 70.8$ & $141.1 \pm 96.1$ & $26.3 \pm 2.9$ & $29.8 \pm 2.2$ & 33 \\
\hline Non-trawled & $13.2 \pm 12.62$ & $149 \pm 158.7$ & $96.4 \pm 32.9$ & $25.4 \pm 2.8$ & $31.1 \pm 2.9$ & 36 \\
\hline$U$ & 16 & 16 & 15 & 18 & 46 & \\
\hline $\mathrm{p}$ & 0.475 & 0.475 & 0.391 & 0.668 & 0.614 & \\
\hline
\end{tabular}

Etmopterus spinax. No significant differences in any of the parameters measured were noted for this species (Table 4). The LFD was dominated by individuals in the 22 to $32 \mathrm{~cm}$ size class at the trawled and non-trawled sites. The LFD analysis showed an apparently healthy population, with most specimens above $\mathrm{L}_{\mathrm{m}}$ and many large specimens above the $\mathrm{L}_{\mathrm{opt}}$ range. The populations in both areas appear to be unexploited.

\section{Community level}

A total of 74 species (10 cephalopods, 17 decapods, 11 Chondrichthyes and 36 teleosts) were identified; teleosts were the dominant taxon both in terms of BI and DI at the non-trawled sites, mainly due to the small bathydemersal fish Chlorophthalmus agassizi. At the trawled sites, Chondrichthyes were dominant in terms of $\mathrm{BI}$, and decapods dominated in terms of DI, mainly due to the black mouth catshark Galeus melastomus in the former case, and the penaeid shrimp Aristaeomorpha foliacea and the pandalid shrimp Plesionika martia in the latter.

BI and DI for all taxonomic groups examined were significantly higher at the non-trawled sites (MannWhitney $U$-test $\mathrm{p}<0.05$; Table 5), with overall biomass (BI) more than 4 times, and number of individuals (DI) more than 6 times, as high as at the trawled sites. All biodiversity indices were significantly different between the trawled and non-trawled sites except for the Margalef species richness ( $D_{\text {; }}$ Table 5). Surprisingly, the taxonomic diversity indices gave different results from the classical diversity indices, with no significant differences for taxonomic diversity $(\Delta)$ and variation in taxonomic distinctness $\left(\Lambda^{+}\right)$. Taxonomic distinctness $\left(\Delta^{*}\right)$ was significantly higher at the trawled sites (Table 5). 
Higher intercepts were recorded in the biomass size spectra for the non-trawled sites for all taxonomic groups examined, reflecting the higher biomass detected at the non-trawled sites in the previous analysis (Fig. 3). The slopes were also quite similar except for teleosts, which had a steeper negative slope at the non-trawled site $(-0.2518$ versus -0.1773$)$ due to the relatively higher proportion of smaller species (Helicolenus dactylopterus dactylopterus and Merluccius merluccius) in the community.
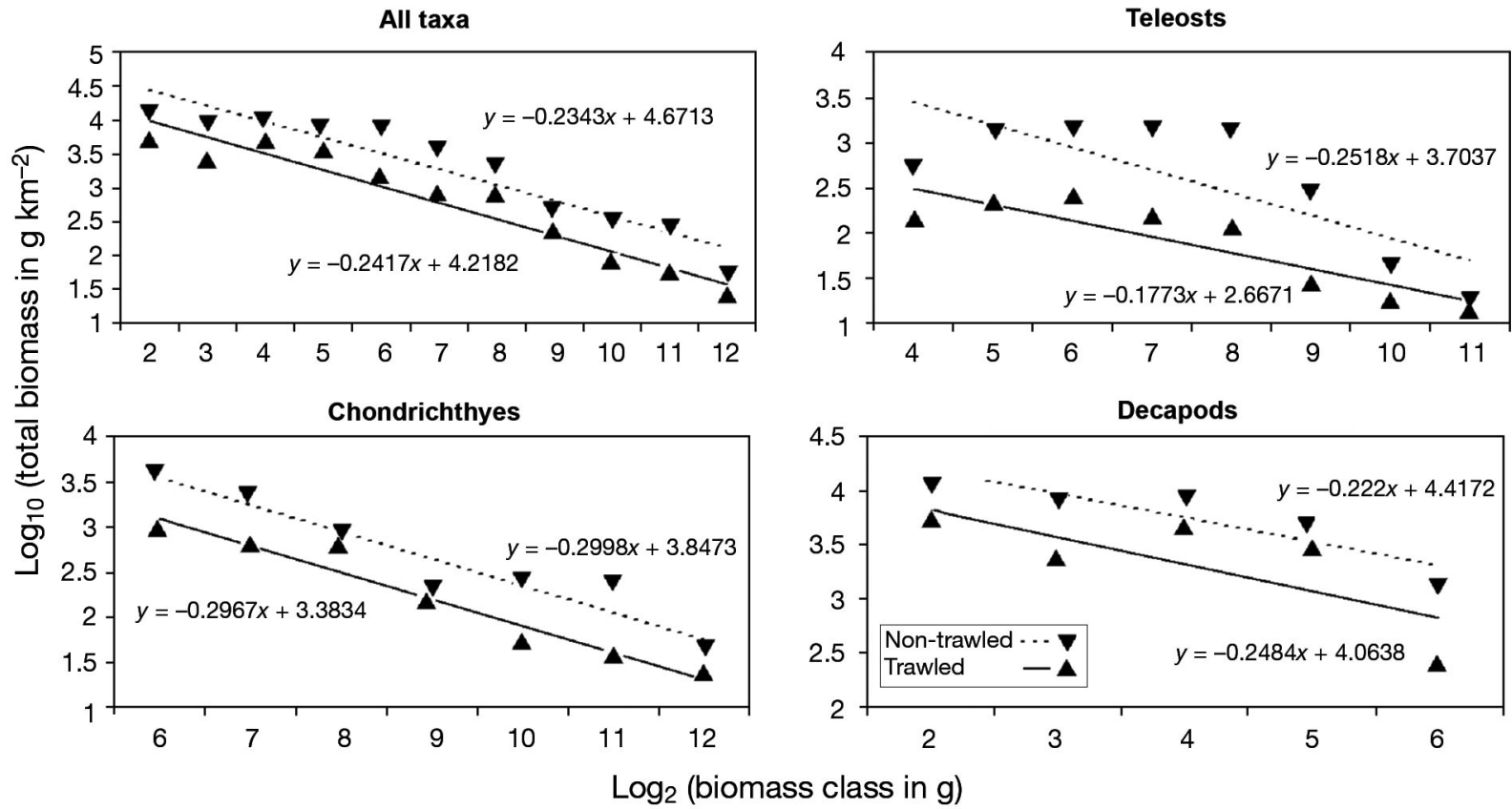

Fig. 3. Biomass size spectra for the different taxonomic groups at trawled and non-trawled sites. Class numbers indicate the lower limit of each class, i.e. class $2=2-2.99$, class $3=3-3.99$, etc.
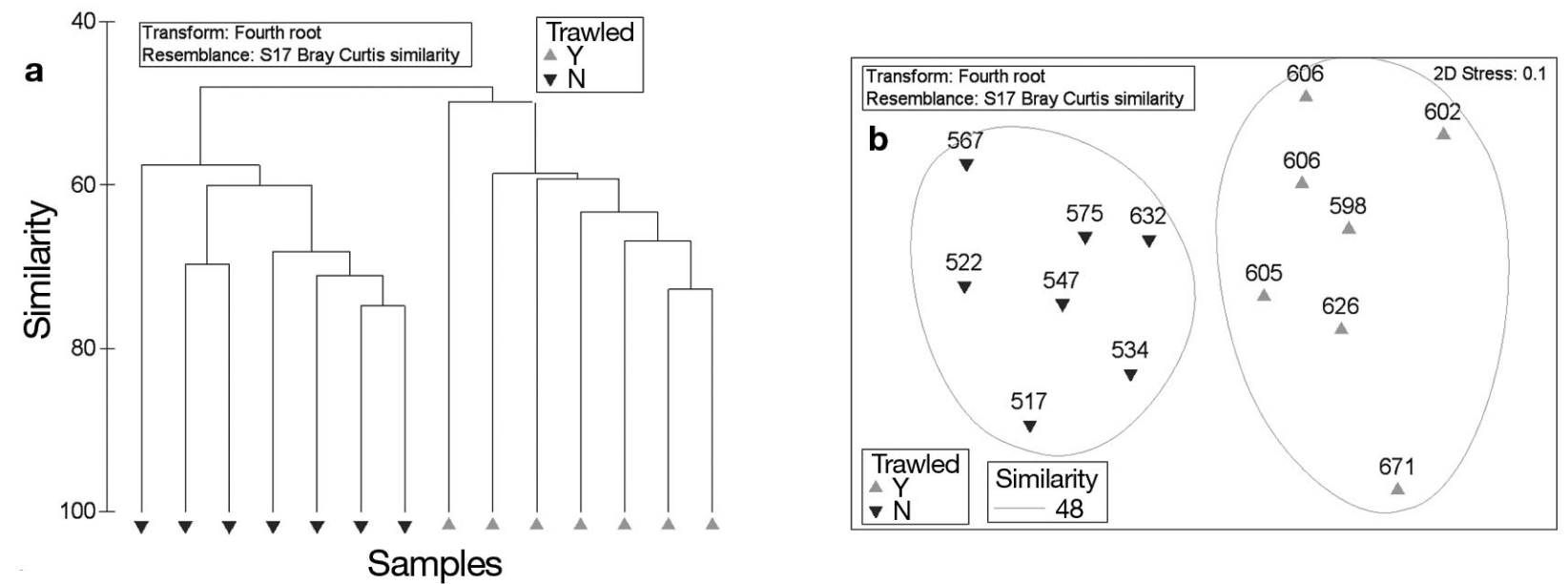

Fig. 4. Results of the multivariate analysis for the sampling stations at trawled (Y) and non-trawled (N) sites based on the biomass data (BI), showing (a) the group average cluster analysis and (b) the non-metric multidimensional scaling plot. Ovals in

(b): groups generated by cluster analysis 
trawled sites. Species other than the ones mentioned earlier, such as the demersal sharks Heptranchias perlo and Centrophorus granulosus and commercial

Table 5. Results of the Mann-Whitney $U$ test for community indicators (mean $\pm \mathrm{SD}$ ) between the trawled and nontrawled sites. See Table 3 for indicator definitions and units. ${ }^{*} \mathrm{p}<0.05$

\begin{tabular}{|lcccc|}
\hline Indicator & Trawled & Non-trawled & $U$ & $\mathrm{p}$ \\
\hline$\overline{\mathrm{BI}}_{\text {total }}$ & $157.9 \pm 99.6$ & $704.0 \pm 269.5$ & 0 & $0.002^{*}$ \\
$\overline{\mathrm{BI}}_{\text {teleosts }}$ & $38.5 \pm 14.1$ & $80.4 \pm 39.8$ & 0 & $0.009^{*}$ \\
$\overline{\mathrm{BI}}_{\text {Chondrichthyes }} 84.2 \pm 77.9$ & $263.2 \pm 149.4$ & 7 & $0.025^{*}$ \\
$\overline{\mathrm{BI}}_{\text {decapods }}$ & $30.7 \pm 26.7$ & $355.1 \pm 187.5$ & 4 & $0.002^{*}$ \\
$\overline{\mathrm{DI}}_{\text {total }}$ & $3032 \pm 949$ & $20041 \pm 9089$ & 0 & $0.002^{*}$ \\
$\overline{\mathrm{DI}}_{\text {teleosts }}$ & $1772 \pm 612$ & $5376 \pm 2115$ & 0 & $0.002^{*}$ \\
$\overline{\mathrm{DI}}_{\text {Chondrichthyes }} 269 \pm 209$ & $1013 \pm 602$ & 4 & $0.009^{*}$ \\
$\overline{\mathrm{DI}}_{\text {decapods }}$ & $990 \pm 454$ & $13556 \pm 9085$ & 0 & $0.002^{*}$ \\
$\overline{\mathrm{S}}$ & $21.00 \pm 2.08$ & $27.14 \pm 4.18$ & 1 & $0.002^{*}$ \\
$\overline{1-\lambda}$ & $0.80 \pm 0.02$ & $0.85 \pm 0.08$ & 7 & $0.025^{*}$ \\
$\overline{\mathrm{D}}$ & $4.08 \pm 0.31$ & $4.04 \pm 0.71$ & 19 & 0.482 \\
$\overline{\mathrm{H}}^{\prime}$ & $1.98 \pm 0.13$ & $2.39 \pm 0.23$ & 5 & $0.013^{*}$ \\
$\overline{\mathrm{J}^{\prime}}$ & $0.65 \pm 0.03$ & $0.73 \pm 0.08$ & 7 & $0.025^{*}$ \\
$\bar{\Delta}$ & $61.71 \pm 4.19$ & $58.82 \pm 6.36$ & 9 & 0.227 \\
$\overline{\Delta^{*}}$ & $77.30 \pm 5.82$ & $69.49 \pm 2.83$ & 4 & $0.013^{*}$ \\
\hline$\Lambda^{+}$ & $750.34 \pm 97.56$ & $678.67 \pm 68.01$ & 13 & 0.225 \\
\hline
\end{tabular}

species like Merluccius merluccius and Phycis blennoides, were responsible for the higher BI at the non-trawled sites (Table 6). It is worth noting that certain elasmobranchs, including Scyliorhinus canicula, Raja oxyrhinchus and particularly C. uyato, which is a very rare species in the Mediterranean (Serena 2005), were only recorded at the nontrawled sites (Table 5). ANOSIM showed that the groups identified by the multivariate techniques were also significantly different $(R=0.728$, $p<0.05)$.

\section{DISCUSSION}

\section{Population structure}

The length frequency distribution of the red shrimp Aristaeomorpha foliacea showed a high proportion of individuals in the 33 to $42 \mathrm{~mm}$ CL range, mainly males, at both trawled and non-trawled sites. However, there was a higher abundance of small individuals (24 to $33 \mathrm{~mm}$ ) at the non-trawled sites, whereas there was a higher abundance of large individuals (54 to $63 \mathrm{~mm}$ ) at the trawled sites; in both cases, these individuals were mainly females. The difference may be attributed to a larger mortality of juvenile females

Table 6. Species which contributed to $90 \%$ of the similarity as determined by the SIMPER procedure. BI: biomass index; Diss/SD: dissimilarity $\div$ standard deviation; Contribution \%: \% contribution to Diss/SD; Cumulative \%: cumulative \% of the \% contribution to Diss/SD. Subscripts - t: teleost; e: elasmobranch; d: decapod crustacean; c: chimaera; m: cephalopod mollusc

\begin{tabular}{|c|c|c|c|c|c|c|}
\hline \multirow[t]{2}{*}{ Species } & \multicolumn{2}{|c|}{ Mean BI $\left(\mathrm{kg} \mathrm{km}^{-2}\right)$} & \multicolumn{4}{|c|}{ Mean dissimilarity $=77.87$} \\
\hline & Trawled & Non-trawled & $\begin{array}{l}\text { Mean } \\
\text { Diss }\end{array}$ & $\begin{array}{l}\text { Diss/ } \\
\text { SD }\end{array}$ & $\begin{array}{c}\text { Contribution } \\
(\%)\end{array}$ & $\begin{array}{c}\text { Cumulative } \\
(\%)\end{array}$ \\
\hline Chlorophthalmus agassizi $_{(\mathrm{t})}$ & 0.24 & 142.46 & 16.84 & 1.22 & 21.62 & 21.62 \\
\hline Galeus melastomus $_{(\mathrm{e})}$ & 40.88 & 84.82 & 8.33 & 1.25 & 10.69 & 32.31 \\
\hline Helicolenus dactylopterus dactylopterus $_{(\mathrm{t})}$ & 7.03 & 72.75 & 7.01 & 1.06 & 9.00 & 41.31 \\
\hline Heptranchias perlo $_{(\mathrm{e})}$ & 15.12 & 50.49 & 5.52 & 1.16 & 7.09 & 48.41 \\
\hline Centrophorus granulosus $_{(\mathrm{e})}$ & 9.72 & 46.44 & 5.24 & 0.71 & 6.73 & 55.13 \\
\hline Nephrops norvegicus $_{(\mathrm{d})}$ & 1.40 & 33.77 & 3.39 & 1.45 & 4.35 & 59.48 \\
\hline Merluccius merluccius $_{(\mathrm{t})}$ & 1.08 & 27.44 & 3.09 & 2.11 & 3.96 & 63.45 \\
\hline Hoplostethus mediterraneus $_{(\mathrm{t})}$ & 1.58 & 28.08 & 2.73 & 1.01 & 3.51 & 66.95 \\
\hline Aristaeomorpha foliacea $a_{(\mathrm{d})}$ & 26.32 & 28.48 & 1.97 & 1.44 & 2.53 & 69.48 \\
\hline Phycis blennoides $_{(\mathrm{t})}$ & 3.56 & 14.87 & 1.93 & 0.93 & 2.47 & 71.95 \\
\hline Scyliorhinus canicula $_{(\mathrm{e})}$ & 0 & 18.53 & 1.90 & 1.12 & 2.45 & 74.40 \\
\hline Raja oxyrinchus $_{(\mathrm{e})}$ & 0 & 13.68 & 1.67 & 0.82 & 2.15 & 76.54 \\
\hline 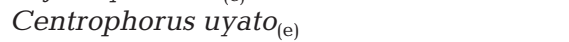 & 0 & 17.93 & 1.66 & 0.40 & 2.13 & 78.67 \\
\hline Nezumia sclerorhynchus $_{(\mathrm{t})}$ & 3 & 14.46 & 1.59 & 0.95 & 2.05 & 80.72 \\
\hline Chimaera monstrosa $_{(\mathrm{c})}$ & 1.70 & 10.92 & 1.23 & 1.15 & 1.57 & 82.29 \\
\hline Coelorhynchus coelorhynchus $_{(\mathrm{t})}$ & 1.18 & 10.15 & 1.18 & 1.40 & 1.51 & 83.81 \\
\hline${\text { Etmopterus } \operatorname{spinax}_{(\mathrm{e})}}$ & 7.51 & 11.29 & 1.17 & 0.96 & 1.50 & 85.30 \\
\hline Plesionika martia $_{(\mathrm{d})}$ & 3.37 & 11.25 & 1.10 & 1.47 & 1.42 & 86.72 \\
\hline Dalatias licha $_{(\mathrm{e})}$ & 9.21 & 0 & 0.91 & 0.39 & 1.17 & 87.89 \\
\hline Gadiculus argenteus $_{(\mathrm{t})}$ & 0 & 7.01 & 0.85 & 0.89 & 1.09 & 88.98 \\
\hline Todarodes sagittatus $_{(\mathrm{m})}$ & 4.47 & 3.91 & 0.76 & 0.84 & 0.98 & 89.96 \\
\hline Hymenocephalus italicus $_{(\mathrm{t})}$ & 1.27 & 5.57 & 0.74 & 0.75 & 0.96 & 90.92 \\
\hline
\end{tabular}


(24 to $33 \mathrm{~mm}$ ) at the trawled sites, likely as a consequence of the full retention by the commercial fishing cod ends (Ragonese et al. 1994). However, scavenging activity may be the main reason for the presence of large shrimps at the trawled sites. The higher number of large females (54 to $63 \mathrm{~mm}$ ) at the trawled sites is most probably due to the movement of large individuals into the trawling lane as a result of the temporary increase in food supply that occurs due to the increased mortality of organisms following the passage of a trawl (Kaiser \& Spencer 1994, Ramsay et al. 1998). A. foliacea is known to be an opportunistic predator and scavenger (Bello \& Pipitone 2002, Chartosia et al. 2005), which supports the idea that the shrimps are moving into the trawled sites.

This species appears to be quite resilient to trawling pressure, as no overall differences in biomass were detected between the 2 sites. However, a recent overexploitation of the stock was detected in the Strait of Sicily (Bianchini et al. 2003, Cardinale et al. 2009). The results of the LFD analysis can be explained considering the basic features of the associated bottom trawling fleet that uses very fine mesh cod-ends and consequently the size at first capture is almost coincident with the size of recruitment. The resulting growth overfishing is compensated for by a continuous supply of recruits and the high growth rates that occur in the first year of life (Ragonese et al. 1994).

Elsewhere in the Mediterranean, studies on the population structure of Aristaeomorpha foliacea in areas with different levels of fishing pressure identified a maximum CL of $62 \mathrm{~mm}$ (Papaconstantinou \& Kapiris 2003), which is less than that recorded in this study (maximum CL: $65 \mathrm{~mm}$ trawled; $60 \mathrm{~mm}$ nontrawled). However, in the Strait of Sicily, despite the intensive fishing for the species since the early 1980s, Ragonese et al. (1994) reported a relatively high number of large-sized shrimps.

No differences were noted in the LFD for Plesionika martia except for higher numbers of individuals at the trawled sites. This may indicate that this species is resilient, possibly due to its reproductive capacity, small size and fast population growth (Company \& Sardà 1997). However, since both shrimps (Aristaeomorpha foliacea and P. martia) are not strictly benthic but bentho-pelagic, movement between the trawled and non-trawled sites may be the reason for the lack of difference, especially given the large distances over which these shrimps migrate (ca. 30 km; Sardá et al. 1997, Relini et al. 2000)

For Nephrops norvegicus and Helicolenus dactylopterus dactylopterus, the main difference was in the larger number of individuals (16 and 6 times higher, respectively) at the non-trawled sites. Both species are considered sedentary and benthic; $N$. norvegicus lives in mud burrows, and $H$. dactylopterus dactylopterus is a sit-and-wait predator (Uiblein et al. 2003). Both species display limited movement and migration. However, some movement from the adjacent non-trawled areas to the trawled site might occur, since most size classes were recorded at both types of site. Movements might be related to scavenging activity. Indeed, for $H$. dactylopterus dactylopterus, no significant difference was detected between the maximum TL in trawled and non-trawled areas. The LFD for the non-trawled areas also showed that the population was better structured, as has also been recorded in the western Mediterranean for areas with low fishing pressure (Ribas et al. 2006). The lack of individuals in the 10 to $18 \mathrm{~cm}$ size class may be due to the depth at which samples were collected, as this size fraction is more common in water shallower than $500 \mathrm{~m}$ (Massuti et al. 2001, Ribas et al. 2006). However, a significant difference was detected in the maximum CL for $N$. norvegicus, although this may be a sampling artefact due to the low number of specimens collected from the trawled sites. The LFD analysis showed that the current level of fishing activity has led to the overexploitation of both $H$. dactylopterus dactylopterus and N. norvegicus.

The other 2 species investigated were sharks that are opportunistic feeders with documented scavenging activity (Cortés 1999). For Galeus melastomus, BI was 2 times and DI was 4 times as high at nontrawled sites than at trawled sites, mostly due to the higher number of individuals in the 22 to $32 \mathrm{~cm}$ size class range. This may imply a higher fishing mortality of juveniles at the trawled sites, possibly as a consequence of the destruction of eggs and displacement, together with recruitment overexploitation. Furthermore, large individuals of $G$. melastomus were more common at the trawled sites with a significantly higher TL. This may be due to the increase in scavenging activity of the species; adults that live in deep water can travel a considerable distance in response to increased food availability (Jones et al. 2003). For Etmopterus spinax, no major differences were detected except for a larger number of individuals in the 30 to $32 \mathrm{~cm}$ size class at the non-trawled sites. The lack of differences may be due to the high tolerance of the species to trawling.

Overall, populations of the relatively sedentary Nephrops norvegicus and Helicolenus dactylopterus dactylopterus had the strongest negative response to 
trawling, while the 2 fast-growing decapod species Plesionika martia and Aristaeomorpha foliacea were much more resilient to trawling. Scavenger species such as Galeus melastomus and Etmopterus spinax seem to be moderately affected by trawling.

Evidence from this study suggests that the populations that occur in the trawled areas are maintained or replenished by high population recruitment rates from the areas protected from trawling. Fishing activities are usually the chief cause of mortality for the first few age groups of Mediterranean demersal fishes and shrimps. The deep-water slope areas protected from trawling within the Maltese $25 \mathrm{n}$ mile zone allow the production of juvenile individuals that are protected from mortality due to fishing. Although these areas are legally protected, other factors contribute to the effectiveness of the protection, including rugged seabed topography, deep-water coral reefs (Schembri et al. 2007), World War II ammunition dumping sites and wrecks (M. Dimech pers. obs.).

\section{Community structure}

The changes in the deep-slope community structure associated with otter trawling were exemplified by the near absence in trawled areas of species like Chlorophthalmus agassizi. The multivariate community analysis clearly showed a difference between trawled and non-trawled sites. Diversity indices showed that overall, diversity and evenness were higher at the non-trawled sites, although taxonomic distinctness was lower at the non-trawled sites.

The trawled sites had a significantly lower number of species and a lower mean abundance and biomass of individuals. Long-lived species such as Helicolenus dactylopterus dactylopterus were more abundant at the non-trawled sites both in terms of DI and BI. Changes in communities to those dominated by small and fast-growing opportunists have been observed to be a general community response to trawling disturbance (Lindeboom \& de Groot 1998, Thrush \& Dayton 2002, Hiddink et al. 2006). The alteration of the population structure of sedentary species such as Nephrops norvegicus and H. dactylopterus dactylopterus observed in the present study is consistent with the effect of trawling, with reduced biomass, reduced abundance and a change in population structure. The change in community structure is also evident from the dominance of small-bodied and more resilient fauna (Aristaeomorpha foliacea and Plesionika martia). Species of Chondrichthyes, which typically have a slow population growth, such as Heptranchias perlo, Centrophorus granulosus, Centrophorus uyato and Chimaera monstrosa were common at the non-trawled sites but rare at the trawled sites. Small-sized fishes such as Chlorophthalmus agassizi (maximum TL $40 \mathrm{~cm}$ ), Hoplosteutus mediterraneus (42 cm), Nezumia sclerorhynchus $(36 \mathrm{~cm})$, Coelorinchus coelorhincus $(48 \mathrm{~cm})$ and Gadiculus argenteus $(15 \mathrm{~cm})$ were also more common at the non-trawled sites. Thus the trawling activities are not only having an impact on the large individuals but also on the small-sized fish, which is contrary to what has been recorded in other areas (Rice \& Gislason 1996, Jennings et al. 1999). However, this was not evident in the size spectra analysis, probably due to the presence of a larger number of overall small-sized juvenile fishes and decapods at the trawled sites. In summary, the trawling-induced changes in the species composition and in the population structure led to a more homogeneous ecosystem (Thrush \& Dayton 2002), with fewer species (lower diversity) and dominance by opportunistic species.

Trawling can result in large-scale ecological effects, including the degradation of communities, overfishing of demersal resources and depletion of populations (Hall 1999, Kaiser \& de Groot 2000). New trawling sites in the Mediterranean, and especially trawling grounds for decapod shrimps, are known to be 'groomed' by being repetitively trawled before the commercial operation starts fully exploiting the demersal resources. Fishers argue that preparing a site is beneficial to the capture of red shrimps since trawling activities remove all of the non-commercial catch and result in a better yield of shrimps, which in their view lie 'underneath' the non-commercial catch (pers. comm.). This belief of red shrimp fishers is borne out by the results of our study, which has shown that the ecology of the deep slope is altered by the trawling activity to favour opportunistic species like red shrimp. Furthermore, since trawling activities reduce species richness, abundance and biomass, reduced amounts of noncommercial species are caught with each haul and hence less time is wasted in sorting the catch into target and non-target species. Apparently, repeated trawling also favours the production of larger individuals of red shrimp as shown by the LFD.

\section{Management implications}

This study has provided evidence for an alteration of the deep-slope, muddy-bottom populations and communities of the central Mediterranean due to 
fishing. However, the main target species have shown high resilience to trawling. Bottom trawling is responsible for a high share of the total demersal catches worldwide (Caddy 1993), and due to the increasing demand for fishery products, this industry is bound to last for many years in the absence of an equally effective harvesting technique for the target species. In order to sustainably exploit resources with minimal ecological impacts and in line with the ecosystem approach to fisheries management, instead of establishing reserves within a large fished geographical area, the opposite management approach could be taken by establishing trawling lanes in a large protected geographical area. The setting up of designated trawling lanes would ensure a continuous supply of demersal fishery resources. The trawled lanes surveyed in the present study are trawled constantly throughout the year and fished whenever the weather permits. Only trawlers $<24 \mathrm{~m}$ are allowed to fish in these areas. Fishers also restrict their activities to the trawling lane since it yields good catches of red shrimps, and the lane is relatively free from obstructions which may damage the net, such as limestone slabs used in the fish aggregating device (FAD) fishery which cover the entire seabed around the islands (Pace et al. 2007). The impact of the trawling activities is therefore limited to the trawling lanes and thus minimises the effects on species with slow growth and low resilience. Such restrictions also ensure high catches, as the non-trawled areas surrounding the trawling lanes act as refugia that supply the trawling lanes with a constant influx of individuals, which may then be harvested. However, such an approach to management may be possible only in waters under national jurisdiction where fisheries managers have control. The situation will be different in waters outside national jurisdiction and on the high seas, where management of the open access resources is much more difficult since it then falls within the remit of the regional fisheries management organisations; here, enforcing this possible management measure will be a daunting task.

Controlled fishing in specific areas within the Maltese $25 \mathrm{n}$ mile FMZ has maintained the community and population structure in the non-trawled areas. Since the latter areas have not experienced any commercial trawl fishing activity, they provide a rare baseline that may approach a near-pristine system. The study has shown that although a high-impact fishing activity such as trawling takes place within the zone, since this activity is restricted to specific areas, the impacts on the ecosystem are very localised (Pitcher et al. 2009) and did not appear to spill over to the surrounding areas. This also has implications for the management of marine protected areas (MPAs) at a scale similar to or larger than the Maltese $25 \mathrm{n}$ mile zone, such that fishing activity could be permitted in specific places or zones without necessarily affecting the overall conservation objectives of MPAs. Such a zoning approach would enable fishers to utilise the ecosystem services provided by MPAs in a sustainable way.

Acknowledgements. We thank R. Pace and F. P. Gravino and the crew of the RV 'Sant' Anna' for their effort and support during sampling. This research was funded by grants from the Malta Centre for Fisheries Science (M.D.) and the University of Malta (P.J.S.), for which we are grateful.

\section{LITERATURE CITED}

Bello G, Pipitone C (2002) Predation on cephalopods by the giant red shrimp Aristaeomorpha foliacea. J Mar Biol Assoc UK 82:213-218

Bertrand JA, Gil de Sola L, Papaconstantinou C, Relini G, Souplet A (2002) The general specifications of the MEDITS surveys. Sci Mar 66(Suppl 2):9-17

Beverton RJH, Holt SJ (1957) On the dynamics of exploited fish populations. Fish Fish Ser 11. Chapman \& Hall, London

Bianchini ML, Ragonese S, Levi D (2003) Management hypotheses to improve yield-per-recruit and economic returns in the red shrimp (Aristaemorpha foliacea) fishery of southern Sicily (Mediterranean Sea). (Ipotesi gestionali per migliorare lo stato del gambero rosso). J Northwest Atl Fish Sci 31:233-243

Caddy JF (1993) Some future perspectives for assessment and management of Mediterranean fisheries. Sci Mar 57 : 121-130

> Caddy JF (2000) Marine catchment basin effects versus impacts of fisheries on semi-enclosed areas. Effects of fishing on the structure and functioning of estuarine and nearshore ecosystems. ICES J Mar Sci 57:628-640

Cardinale M, Rätz HJ, Cheilari A (2009) Report of the SGMED-09-02 Working Group on the Mediterranean. Part I. Scientific and technical research series. Publications Office of the European Union, Luxembourg

Cartes JE (1993) Deep-sea decapod fauna of the western Mediterranean: bathymetric distribution and biogeographic aspects. Crustaceana 65:29-40

Cartes JE, Sardà F (1992) Abundance and diversity of decapod crustaceans in the deep-Catalan Sea (Western Mediterranean). J Nat Hist 26:1305-1323

Cartes JE, Maynou F, Sardà F, Company JB, Lloris D, Tudela S (2004) Part I. The Mediterranean deep-sea ecosystems: an overview of their diversity, structure, functioning and anthropogenic impacts. In: Tudela S, Simard F (eds) The Mediterranean deep-sea ecosystems: an overview of their diversity, structure, functioning and anthropogenic impacts, with a proposal for conservation. IUCN, Málaga and WWF, Rome, p 9-38

> Chartosia N, Tzomos TH, Kitsos MS, Karani I, Tselepides A, Koukouras A (2005) Diet comparison of the bathyal shrimps, Aristeus antennatus (Risso, 1816) and Aristaeo- 
morpha foliacea (Risso, 1827) (Decapoda, Aristeidae) in the eastern Mediterranean. Crustaceana 78:273-284

> Choi JS, Frank KT, Leggett WC, Drinkwater K (2004) Transition to an alternate state in a continental shelf ecosystem. Can J Fish Aquat Sci 61:505-510

Clarke KR, Warwick RM (1994) Similarity-based testing for community pattern: the two-way layout with no replication. Mar Biol 118:167-176

> Clarke KR, Warwick RM (1998) A taxonomic distinctness index and its statistical properties. J Appl Ecol 35: 523-531

Clarke KR, Warwick RM (2001a) Change in marine communities: an approach to statistical analysis and interpretation, 2nd edn. PRIMER-E, Plymouth

> Clarke KR, Warwick RM (2001b) A further biodiversity index applicable to species lists: variation in taxonomic distinctness. Mar Ecol Prog Ser 216:265-278

> Company JB, Sardà F (1997) Reproductive patterns and population characteristics in five deep-water pandalid shrimps in the Western Mediterranean along a depth gradient (150-1100 m). Mar Ecol Prog Ser 148:49-58

Cortés E (1999) Standardized diet compositions and trophic levels of sharks. ICES J Mar Sci 56:707-717

D'Onghia G, Capezzuto F, Mytilineou C, Maiorano P and others (2005) Comparison of the population structure and dynamics of Aristeus antennatus (Risso, 1816) between exploited and unexploited areas in the Mediterranean Sea. Fish Res 76:22-38

de Juan S, Thrush S, Demestre M (2007) Functional changes as indicators of trawling disturbance on a benthic community from a fishing ground (NW Mediterranean). Mar Ecol Prog Ser 334:117-129

Demestre M, Sánchez P, Kaiser MJ (2000) The behavioural response of benthic scavengers to otter-trawling disturbance in the Mediterranean. In: Kaiser MJ, de Groot SJ (eds) Effects of fishing on non-target species and habitats. Blackwell Science, London, p 121-129

$>$ Dimech M, Camilleri M, Hiddink JG, Kaiser MJ, Ragonese S, Schembri PJ (2008) Differences in demersal community structure and body-size spectra within and outside the Maltese Fishery Management Zone (FMZ). Sci Mar 72:669-682

> Duplisea DE, Kerr SR, Dickie LM (1997) Demersal fish biomass size spectra on the Scotian Shelf, Canada: species replacement at the shelfwide scale. Can J Fish Aquat Sci 54:1725-1735

Fiorentini L, Dremière PY, Leonori L, Sala A, Palumbo V (1999) Efficiency of the bottom trawl used for the Mediterranean international trawl survey (MEDITS). Aquat Living Resour 12:187-205

$>$ Froese R, Binohlan C (2000) Empirical relationships to estimate asymptotic length, length at first maturity and length at maximum yield per recruit in fishes, with a simple method to evaluate length frequency data. J Fish Biol 56:758-773

- Gristina M, Bahri T, Fiorentino F, Garofalo G (2006) Comparison of demersal fish assemblages in three areas of the Strait of Sicily under different trawling pressure. Fish Res 81:60-71

Hall SJ (1999) The effects of fishing on marine ecosystems and communities. Blackwell Scientific Publications, Oxford

Hiddink JG, Jennings S, Kaiser MJ, Quelros AM, Duplisea DE, Piet GJ (2006) Cumulative impacts of seabed trawl disturbance on benthic biomass, production, and species richness in different habitats. Can J Fish Aquat Sci 63: 721-736

Jennings S, Greenstreet SPR, Reynolds JD (1999) Structural change in an exploited fish community: a consequence of differential fishing effects on species with contrasting life histories. J Anim Ecol 68:617-627

Jennings S, Dinmore TA, Duplisea DE, Warr KE, Lancaster JE (2001) Trawling disturbance can modify benthic production processes. J Anim Ecol 70:459-475

> Jones EG, Tselepides A, Bagley PM, Collins MA, Priede IG (2003) Bathymetric distribution of some benthic and benthopelagic species attracted to baited cameras and traps in the deep eastern Mediterranean. Mar Ecol Prog Ser 251:75-80

Kaiser MJ, de Groot SJ (eds) (2000) The effects of fishing on non-target species and habitats. Blackwell Scientific Publications, Oxford

Kaiser MJ, Spencer BE (1994) Fish scavenging behaviour in recently trawled areas. Mar Ecol Prog Ser 112:41-49

Kaiser MJ, Clarke KR, Hinz H, Austen MCV, Somerfield PJ, Karakassis I (2006) Global analysis and prediction of the response of benthic biota and habitats to fishing. Mar Ecol Prog Ser 311:1-14

Lindeboom HJ, de Groot SJ (eds) (1998) The effects of different types of fisheries on the North Sea and Irish Sea benthic ecosystems. NIOZ-rapport 1998-1, RIVO-DLO rapport C003/98. NIOZ, Texel

Lleonart J (2005) Mediterranean and Black Sea. FAO Fish Tech Pap 457:49-64

Maiorano P, D'Onghia G, Capezzuto F, Sion L (2000) Lifehistory traits of Plesionika martia (Decapoda: Caridea) from the eastern-central Mediterranean Sea. Mar Biol 141:527-539

Massuti E, Moranta J, Gil de Sola L, Morales-Nin B, Prats L (2001) Distribution and population structure of the bluemouth Helicolenus dactylopterus (Pisces: Scorpaenidae) in the Western Mediterranean. J Mar Biol Assoc UK 81: 129-141

Merigot B, Bertrand JA, Gaertner JC, Durbec JP, Mazouni N, Mante C (2007) The multi-component structuration of the species diversity of groundfish assemblages of the east coast of Corsica (Mediterranean Sea): variation according to bathymetric strata. Fish Res 88:120-132

Moranta J, Massutí E, Morales-Nin B (2000) Fish catch composition of the deep-sea crustacean fisheries in the Balearic Islands (western Mediterranean). Fish Res 45: 253-264

Mytilineou C, Castro M, Gancho P, Fourtouni A (1998) Growth studies on Norway lobster, Nephrops norvegicus (L.), in different areas of the Mediterranean Sea and the adjacent Atlantic. Sci Mar 62(Suppl 1):43-60

Pace R, Dimech M, Camilleri M, Schembri PJ (2007) Distribution of discarded limestone slabs used in traditional Maltese lampuki fishery. Rapp Comm Int Mer Méditerr 38:568

Papaconstantinou C, Farrugio H (2000) Fisheries in the Mediterranean. Mediterr Mar Sci 1:5-18

Papaconstantinou C, Kapiris K (2003) The biology of the giant red shrimp (Aristaeomorpha foliacea) at an unexploited fishing ground in the Greek Ionian Sea. Fish Res 62:37-51

Pérès JM (1985) History of the Mediterranean biota and the colonization of the depths. In: Margalef R (ed) Key environments: Western Mediterranean. Pergamon Press, New York, NY, p 198-232 
Pipitone C, Badalamenti F, D'Anna G, Patti B (2000) Fish biomass increase after a four-year trawl ban in the Gulf of Castellammare (NW Sicily, Mediterranean Sea). Fish Res 48:23-30

Pitcher CR, Burridge CY, Wassenberg TJ, Hill BJ, Pioner IR (2009) A large scale BACI experiment to test the effects of prawn trawling on seabed biota in a closed area of the Great Barrier Reef Marine Park, Australia. Fish Res 99: 168-183

Ragonese S, Bianchini L, Gallucci VF (1994) Growth and mortality of the red shrimp Aristaeomorpha foliacea in the Sicilian channel (Mediterranean Sea). Crustaceana 67:348-361

Ragonese S, Andreoli MG, Bono G, Giusto GB, Rizzo P, Sinacori G (2004) Overview of the available biological information on demersal resources of the Strait of Sicily. In: Report of the expert consultation on the spatial distribution of demersal resources in the Straits of Sicily and the influence of environmental factors and fishery characteristics. GCP/RER/010/ITA/MSM-TD-02. FAO MedSudMed Tech Doc 2: FAO, Rome

Ramsay K, Kaiser MJ, Hughes RN (1998) The responses of benthic scavengers to fishing disturbance by towed gears in different habitats. J Exp Mar Biol Ecol 224:73-89

Relini G, Bertrand J, Zamboni A (1999) Sintesi delle conoscenze sulle risorse da pesca dei fondi del Mediterraneo centrale (Italia e Corsica). Biol Mar Mediterr 6(Suppl 1):1-868

Relini M, Maiorana P, D'Onghia G, Orsi-Relini L, Tursi A, Panza M (2000) A pilot experiment of tagging the deep shrimp Aristeus antennatus (Risso 1816). Sci Mar 64: 357-361

Relini G, Carpentieri P, Murenu M (2008) Manuale di istruzione Medits (Medits instruction manual). Biol Mar Mediterr 15(Suppl 2):1-78

Ribas D, Muñoz M, Casadevall M, Gil de Sola L (2006) How does the northern Mediterranean population of Helicolenus dactylopterus dactylopterus resist fishing pressure? Fish Res 79:285-293

Editorial responsibility: Janet Ley, St. Petersburg, Florida, USA
Rice J, Gislason H (1996) Patterns of change in the size spectra of numbers and diversity of the North Sea fish assemblage, as reflected in surveys and models. ICES J Mar Sci 53:1214-1225

Sánchez P, Demestre M, Ramon M, Kaiser MJ (2000) The impact of otter trawling on mud communities in the northwestern Mediterranean. ICES J Mar Sci 57:1352-1358

Sánchez P, Sartor P, Recasens L, Ligas A, Martin J, De Ranieri S, Demestre M (2007) Trawl catch composition during different fishing intensity periods in two Mediterranean demersal fishing grounds. Sci Mar 71:765-773

Sardá F, Maynou F, Tallo L (1997) Seasonal and spatial mobility patterns of rose shrimp Aristeus antennatus in the western Mediterranean: results of a long-term study. Mar Ecol Prog Ser 159:133-141

Sartor P, Biagi F, Mori M, Sbrana M (1999) Analysis of the discard of some important demersal species in the trawl fishery of the northern Tyrrhenian Sea. Biol Mar Mediterr 6:605-608

Schembri PJ, Dimech M, Camilleri M, Page R (2007) Living deep-water Lophelia and Madrepora corals in Maltese waters (Strait of Siciliy, Mediterranean Sea). Cah Biol Mar 48:77-83

Serena F (2005) Field identification guide to the sharks and rays of Mediterranean and Black Sea. FAO species identification guide for fishery purposes. FAO, Rome

Smith CJ, Papadopoulou KN, Diliberto S (2000) Impact of otter trawling on an eastern Mediterranean commercial trawl fishing ground. ICES J Mar Sci 57:1340-1351

Stefanescu C, Rucabado J, Lloris D (1992) Depth-size trends in western Mediterranean demersal deep-sea fishes. Mar Ecol Prog Ser 81:205-213

- Thrush SF, Dayton PK (2002) Disturbance to marine benthic habitats by trawling and dredging: implications for marine biodiversity. Annu Rev Ecol Syst 33:449-473

Uiblein F, Lorance P, Latrouite D (2003) Behaviour and habitat utilization of seven fish species on the Bay of Biscay continental slope, NE Atlantic. Mar Ecol Prog Ser 257: 223-232

Submitted: May 26, 2011; Accepted: November 1, 2011 Proofs received from author(s): February 22, 2012 